\title{
A FEW REMARKS ON LEgal TranSLATION AND INTERCULTURAL ENCOUNTERS
}

\author{
IWONA WITCZAK-PLISIECKA \\ University of Lodz \\ iwona.plisiecka@ uni.lodz.pl
}

\begin{abstract}
The text offers comments on legal translation and its special nature. It is argued that legal translation is much different from other types of specialised translations. Unlike the language of engineering or medicine, legal language does not only refer to the related specialised practice, i.e. the law, but constitutes legal reality, being at the same time an instrument with which legal disputes are resolved. In the context of translation, legal language is particularly challenging as the process of finding equivalence is not restricted to interlinguistic level, but invites both intralinguistic and intersemiotic considerations. Moving not only between different natural languages, but also between different legal cultures, legal translators have to face problems that can often be naturally found in intercultural communication.
\end{abstract}

Keywords: equivalence, legal language, legal translation

\section{Introduction}

It is undeniable that legal language as an LSP, a language for specific purposes, is indeed special when compared with other semantically restricted varieties. Unlike the language od engineering, the language of medicine, or academic discourse, it is actional in the sense of defining, constituting and (re)instantiating legal reality. In this context there is a rather natural link between legal language and linguistic pragmatics as the interface of the legal and the linguistic domain provides particularly evident illustrations that saying can and often does mean doing things. Evidently, it was not without reason why John L. Austin, in the process of creating his model of speech act theory in Oxford in the 1940s remained in close cooperation with Herbert L.A. Hart, a key legal philosopher at the time (Sugarman \& Hart 2005; cf. Austin 1962/1975, Witczak-Plisiecka 2013a and the literature cited within). It would be hard to find a field which could exhibit that language is actional in nature in a way more convincing that legal contexts could provide, cf. 
delivering a verdict, finding a defendant guilty or not guilty, imposing obligations and conferring rights.

Law is hardly conceivable without language, whether in the realm of normative texts, or the more vivid communicative events, e.g. legal negotiations, procedures, or counselling. The vast array of legal contexts embraces more and less formal discourses, professional encounters between lawyers and less hermetic language(s) used by mixed parties, e.g. in lawyer-client consultations (cf. e.g. Danet 1980, Witczak-Plisiecka 2005, Fetzer \& Witczak-Plisiecka in press). This complexity requires much communicative legal competence on the part of language users if they are to create linguistic performance which passes as natural in various legal contexts; consequently, there are special requirements that translators who work in such contexts must satisfy.

Although in the common view of ordinary people it may appear that legal translation is all about knowing how to manage legal terms of art, in fact legal translation involves more than that; it involves communication between different cultures. On the most immediate plain this will be between the legal culture and the lay culture, but the many contexts in which translation is needed will also involve encounters between different legal cultures which have different legal institutions, different traditions, and conventions (cf. Hutton 1999). Thus, the problems transcend relatively simple institutional differences such as the difference between the systems of common law and those related to the tradition of Roman law. In many contexts it is indeed more convenient to approach such differences in terms of intercultural differences. In what follows I will provide a short description of the points of difficulty that legal contexts may pose in translation, both on the locutionary, semantic level, i.e. the formal aspect of language, and the pragmatic, intercultural level ${ }^{1}$.

\section{Legal language, translation and equivalence}

The phrase "legal language" is widely used and presupposes a relatively welldefined field, but in reality it opens the whole realm of various encounters within the legal community or where "the legal" meets "the lay" reality. In the attempt to introduce order and transparent typologies, researchers commonly build a divide between, e.g., "the language of the law" and "legal language," where the former is to refer to the language of legal documents, while the latter refers to the language used by lawyers in less fossilised documents (including legal handbooks) or face-to-face interactions. This distinction is marked in English (cf. Crystal 2018, p. 398), but in Poland, in an independent research programme, it was well established by Jerzy Wróblewski (cf. Wróblewski 1948, 1959, 1984), who introduced the distinction between "język prawny" (closer to the English

\footnotetext{
${ }^{1}$ Some of the data included in this paper was earlier published in I. Witczak-Plisiecka (2016).
} 
"language of the law") and "język prawniczy" (closer to the English phrase "legal language"). There have also been attempts to classify different contexts in which legal language is used according to style, mode, and the type of participants involved (cf. Danet 1980, Fetzer \& Witczak-Plisiecka, in press). Traditional (cf. Danet 1980, p. 471) modes included written, spoken-composed, and spokenspontaneous modes, while the styles recognised in legal communication were identified as "frozen" or "formal" (for written and spoken-composed modes), "consultative" (for selected spoken composed and spoken-spontaneous modes), and "casual" (for spoken-spontaneous modes as seen in e.g. lawyer-lawyer conversations or lobby conferences). Such categories has been enriched due to the spread of electronic communication, which has brought about both new forms of expression and a change in conventions, for instance in less formal contexts written and spoken modes can often be clearly merged without affecting the value of communication.

In summary, legal language is best seen as a subfield of natural language, a variety which shares many features recognised as standard, but also shows particular features on the level of lexical, structural, and stylistic choices (cf. an already classic account by Mellinkoff 1963, Tiersma 1999, Gibbons 2003, Witczak-Plisiecka 2001, 2007 and references within). Such features are best seen in the written mode, especially in documents with well-defined format, e.g. statutes, last wills, state constitutions, international treaties.

The lexical level of the English legal language includes "terms of arts", labels for legal institutions, but also lexical items which are rarely used in other contexts. Special attention must be paid to lexical items which may look ordinary, but have special meaning in the law (e.g. the use of "issue" to refer to a child, an offspring, or the use of "consideration" to refer to a move constituting a contract). Uncommon items include somewhat archaic forms and Latin expressions (or French-Norman relicts) that remained alive in legal contexts, but are gone from general discourse (e.g. "sub judice", "in esse", "ejusdem generis").

The language of the law makes use of numerous self-referential deictic expressions (e.g. "aforesaid", "thereinafter", "theretofore", "wheresoever"), while there are hardly any used in general English, with the exception of the adverb "hereby". English legal language also abounds with doublets and triplets, i.e. fixed phrases which include synonymous words (e.g. "null and void", "act and deed", "fraud and deceit", "to aid and abet"). Some of such doublets and triplets can be explained with reference to the history of the English language, e.g. it may often be the case that the synonyms pair the Normal French vocabulary with the AngloSaxon lexis. It may also be the case that historically, the words used differed in their meaning, as in the case of "to give, devise and bequeath" used in last wills and testaments, whose items in the past refered to different types of possessions. Although there is no functional difference today, the phrase is still used. The presence of doublets and triplets may also be a sign of another feature of legal language, i.e. that its form can be instrumental in demonstrating power. 
The use of modal verbs, and especially the deontic use of the verb "shall" is also specific in legal language, where it functions as a vehicle for deontic values rather than prediction. The use of "shall" to impose obligation has been much criticised and shown to be a source of misunderstanding. The least frequent modal verb with its frequency being below 250 per million words (cf. Biber et al. 1999, p. 486) is of special significance in legal contexts, even though its deontic use has been recognised as "marginal" and highly specialised, "peripheral and rare" (cf. e.g. Huddleston 2002, p. 194, Quirk et al. 1992).

On the syntactic level legal language is characterised by a relatively high frequency of nominal and prepositional phrases, a higher frequency of passive constructions, and long elaborate sentences. Technically, a document such as a treaty, or a parliamentary act, can be drafted as one long sentence, but even in documents with traditional punctuation sentences tend to be very long with the average gaining, e.g. between 45 and 55 words (cf. Gotti 2003).

Stylistically, it is highly self-referential and, especially in legislative documents, strives for a balance between precision and openness so that it could be applied in contexts which cannot be fully envisaged at the time of drafting. It is also significant that legal texts are endowed with operational value, kin to the illocutionary force as discussed in linguistics. They are phrased to be performative, to influence the social structure of the world.

Despite the inherent complexity, legal language is generally perceived as a coherent domain. Partly due to the existence of the features listed above, it is seen as a language apart, a functional variety notoriously inaccessible for people with no expertise in the law, sometimes dubbed not only as a sublanguage, but "legalese", a "gobbledegook", or legal argot. It is further interesting that there are persisting myths related to legal semantics, for instance, it is often believed that "legal meaning" is more stable than ordinary meaning, and that legal texts are stable in their meaning and that they do not easily succumb to (free) interpretation. Such a perspective helps to see law as well-balanced and strong, which, in turn, provides a sense of security with regard to the legal system, including the rights conferred and the obligations imposed. However, legal language inherits all features of natural language, including indeterminacy of meaning.

In addition, legal language is directly connected with legal practice; it constitutes law, and as such may be seen as more than "just" specialised language. It is often pointed out, especially by lawyers, that the language of the law is phrased in such a way that it is only lawyers that are able to interpret it correctly. As pointed out by Wojtczak and Witczak-Plisiecka (2019), the language of the law should not be identified with a system of well-defined, i.e. pre-defined, terms as in fact it requires professional interpretation, whose relevance will vary even within the legal community. Following Frank's (1947) metaphor, in the context of legal documents, the legislator is a composer, whose piece of art will be interpreted by future performers of different kind, different talents, and different levels of expertise in the law. Moreover, the language of the law quite naturally 
involves metaphorical imagery, which poses further difficulties (cf., e.g. Wojtczak, Witczak-Plisiecka \& Augustyn 2017).

All the characteristic features of legal language as described above together with the function that it plays in the social world contribute to the relative difficulty that translators have to face when they engage in working in the field.

It is natural that in discussing translation we consider the problem of equivalence. A good translation is supposed to be faithful, truthful, loyal to the source text and its author. It is also common practice to identify translation with representing meaning across natural languages, and it is often backgrounded that there are similar processes in the context of translating between natural languages and reformulating messages within one natural language. The latter processes bear particular resemblance to translation when reformulation is done between general language and specialised languages, as, for instance, in the context of legal discourse (where discourse means the legal variety, whether spoken or written) and language at large.

Famously, Roman Jakobson (1959) in his theory focused on literary language introduced three main types of equivalence:

1) intralingual equivalence

2) interlingual equivalence, and

3) intersemiotic equivalence.

Naturally, intralingual equivalence is sought within one language through rewording, interlingual equivalence, or as Jakobson dubbed it, "translation proper" refers to translating from one natural language to another, and, finally, intersemiotic equivalence refers to the sameness of meaning between different semiotic systems and involves transmutation between language and, e.g., nonverbal systems, such as visual arts, gestures, etc.

Legal language contexts provide particularly good illustrations that all three types of equivalence, as defined by Jakobson, are relevant for translation practice. They can be relevant even at the level of translating legal documents, not to mention the many legal discourses involving face-to-face interactions, which invite a much wider perspective. Let us now consider selected aspects of how English legal language and the problems of different types of equivalence are related.

\section{Translation in the legal context: Selected problems 3.1. Intralingual equivalence and legal translation}

It may seem that intralingual processes of reformulation are of minor importance for translators; however, there are a few points to be mentioned. Firstly, interpretation of a legal text involves understanding of the terms and phrases used in such a text not only in their immediate linguistic environment, but also on the intertextual plane. In some approaches this complexity is conceptualised in a Bakhtinian (1981, 1986) dialogic perspective (cf. an overview of related 
approaches in Jopek-Bosiacka 2019), where the intralingual interpretation focuses on the internal structure of the text, while the intertextual interpretation involves the interrelations between the text in question and other texts belonging to the same genre, and in general to the same legal system. Thus, any interpretation of a legal text must consider the specificity of legal culture in its entirety and the particular legal culture in which the text belongs. As a result, the intralingual level already necessitates considerations of culture-bound issues, which goes beyond the recognition of e.g. the Roman law system and tradition, or the common law system as even within one legal system terminology may differ across subsystems or genres.

The heading in this section includes both intralingual "translation" and translation proper. Indeed, the word "translation" for reformulation within one language in this context may be more accurate than "equivalence" as it involves "translating" for selected audiences.

One of the many manifestations of "cultural encounters" in the law involves reformulation within one language, which can be directly found in the context of plain language movement. Plain language, or plain legal language, movement is a campaign whose origin can be traced back to 1970s in the united States and the research by Robert Charrow and Veda Charrow (cf. Charrow \& Charrow 1979) focused on the (in)comprehensibility of jury instructions. Charrow and Charrow's (1979) original reflection was that jury members found the instructions given to them quite incomprehensible due to the intricacies of legal language used within. The researchers' conclusion was that legal texts, especially those directed to lay people, should be reformulated so that ordinary people could understand them directly.

An illustrative example of what kind of differences can be expected between the traditional legal register in English and a "plain" variety closer to ordinary language can be found in a speech given by Lord Justice Rix at a Clarity seminar in 2006, later published in Clarity, a journal devoted to plain language movement; a fragment has been quoted in table 1 below:

Table 1: Lord Justice Rix's example of "traditional" and "plain" legal discourse; Speech delivered at a Clarity seminar at Denton Wilde Sapte, 10 Oct 2006;

\begin{tabular}{|l|l|}
\hline The "legalese" version & $\begin{array}{l}\text { Upon any such default, and at any time thereafter, Secured Party } \\
\text { may declare the entire balance of the indebtedness secured hereby, } \\
\text { plus any other sums owed hereunder, immediately due and payable } \\
\text { without demand or notice, less any refund due, and Secured Party } \\
\text { shall have all the remedies of the Uniform Commercial Code. }\end{array}$ \\
\hline The "plain" version & $\begin{array}{l}\text { If I break any of my promises in this document, you can an any } \\
\text { time demand that I immediately pay all that I owe }\end{array}$ \\
\hline
\end{tabular}

Source: http://www.clarity-international.net/journals/56.pdf

In general, any possible reformulation of legal discourse into its "plain" version has as many enthusiasts as opponents. Many non-professional people see 
it as a move in the right direction, but as many or more lawyers see it as distortion which may have a particularly negative impact on legal practice, blurring the division between legal metalanguage, a functional hermetic variety, and everyday discourse where the level of precision is much lower. Whichever the opinion in the context of translation it is necessary that the existing variety in English legal language is recognised and attended to. A legal translator must also be ready to decide how to represent the register found in the source context in the target language, how much of its traditional "charm" should be, and can be, represented in the foreign language version.

Since 1970s plain language movement has spread all around the world and its proponents have also made numerous claims with regard to languages other than English. Within English, demands for reformulation can be found across various legal Englishes belonging to various legal (sub)cultures.

In 1999, as a result of the Plain English Campaign, a number of changes were introduced in the field of the terminology of civil law in England, which received a wide coverage not only in law-oriented circles, but also in popular cites focused on language matters (cf. https://www.worldwidewords.org/articles/probono.htm). As the Master of the Rolls, Lord Harry Wolff, said in his report on Access to Justice $^{2}$. The system of civil justice and the rules which govern it must be broadly comprehensible not only to an inner circle of initiates but to non-professional advisers and, so far as possible, to ordinary people of average ability who are unlikely to have more than a single encounter with the system".

The Access to Justice Act introduced lexical changes within the legal metalanguage in the domain of civil law. For instance, the use of "plaintiff" was abandoned and the term "claimant" introduced into the legal metalanguage. Similarly, the rather archaic term "writ" as in "issue a writ" was replaced with a more transparent "claim form" that can be 'just' presented; a less transparent "give leave" turned into "give permission". Lord Wolff also suggested that the word "pleadings" should be replaced with "statement of case" to bring the civil law language closer to the common language of the people. Furthermore, a number of common law-based labels were changed, e.g. the "Anton Piller order" was replaced with a more explicit "search order", and a "Mariva injunction" was replaced with a "freezing injuction", two terms that could be easily understood without any prior knowledge of the cases in which proper names of Anton Piller and Mariva were involved. Plain English was also chosen to replace selected Latin terms of art. e.g., "sub judice" was replaced with "pending litigation", a "guardian ad litem" with a "litigation friend", as well as "inter partes" and "ex parte" with "with notice" and "without notice" respectively, and "in camera" into "in private".

The changes as above impose a specific system of sense relations within one language. For instance "plaintiff" and "claimant" are synonymous in English at large, but do not work as synonyms within the legal system, where technical

2 cf. Access to Justice Act 1999;

https://www.legislation.gov.uk/ukpga/1999/22/notes/contents 
terminology of criminal law and civil law differs. Thus, there is a complex network of semantic interrelations on the intralinguistic plane, where the status of lexical items depends on their grounding in the legal system, i.e. whether they are approached as metalanguage or ordinary language. Naturally, the intralingual interconnections pose problems for translators looking for interlingual equivalence. For instance, translating the above-mentioned terms into Polish will require the recognition of the source terms and knowing their equivalents, but translating from Polish to English will also require the detailed knowledge of professional terminology with the division into the criminal and the civil law system as only one of the equivalents is going to be fully adequate.

\subsection{Interlingual equivalence and legal translation}

The problem that can be seen in the interface of intralingual and interlingual contexts, especially when different legal Englishes are taken into consideration is that of the names of legal professions. The six most frequently used labels include: "attorney", "solicitor", "barrister", "prosecutor", "advocate", "judge", and "notary". There are also common general terms, such as "lawyer", or less frequently used "advocate". Many of the labels denoting the professions notoriously lack one-to-one equivalents not only in other natural languages, but also across various legal Englishes. In addition, even if there seems to be an appropriate equivalent, it is often the case that the competences associated with the profession differ across both different Englishes and different legal systems.

In summary, a legal translator dealing with an English-language text must pay attention to the fact in which legal culture the text belongs as the competences associated with a particular label may differ along with a difference in the definition of the legal institution in question in a particular culture. There are numerous examples, but one that is specially interested, and particularly visible is that of the names of legal professions. To provide a simple example: an "attorney" can mean 'just' a lawyer, a solicitor, or a prosecutor (as in "district attorney" as used in the United States), while a "notary" in some countries will denote a lawyer, but, for instance, in the United States may denote simply a person employed to perform notarial duties, but there is no requirement that such a person should hold a diploma from a legal department. Thus, it may be misleading to uncritically use the Polish word "notariusz" (the closest English word is "notary") in all contexts as an equivalent for "notary".

Significantly, in recognition of the problems that may arise if an equivalent label is used in the target language, it has been rather common practice that terms, such as "barrister" and "solicitor" would not be translated within the EU legislation, but retained in their English form in different EU official language versions of relevant documents (cf. e.g. CURIA' Verdict C-127/04). In fact in all court documents in the EU, for instance in the documents of the Court of Justice of the European Union, names of legal professions are cited in their original, 
native language versions. This can be seen in Table 1 one below, where not only "barrister" and "solicitor", but also other legal professional labels are left without translation. For instance, "avoccato dello Stato" for an Italy-based professional, and the acronym QC (for "Queen's Councel"), a title used for a senior lawyer who can act as a senior counsel in court cases in the Commonwealth, are both used in their original form in four different official language versions: English, Polish, French, and Finnish.

The strategy dictating not to translate names of legal professions even in the context of case proceedings is pragmatic in nature. It is more practical not to provide an equivalent that by definition will be imperfect and instead invite audiences to recognise the "foreignness" of the words, and consequently, categories.

Table 2: Four language versions of a fragment of a CURIA document (emphasis added) (Source: InfoCuria Case-Law; C-127/04 - O’Byrne; https://curia.europa.eu)

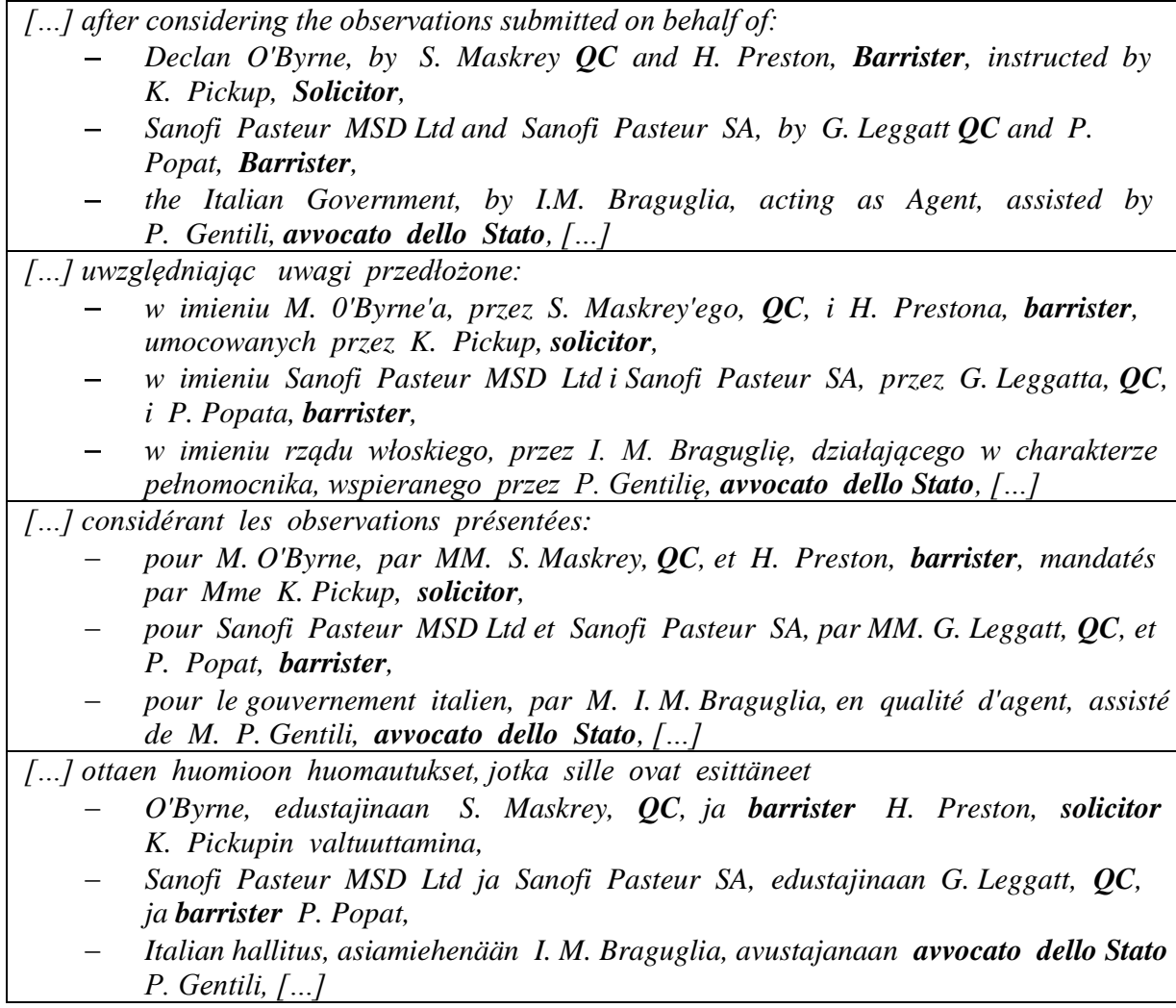

- w imieniu M. O'Byrne'a, przez. S. Maskrey'ego, QC, i H. Prestona, barrister, umocowanych przez K. Pickup, solicitor,

- $\quad$ w imieniu Sanofi Pasteur MSD Ltd i Sanofi Pasteur SA, przez G. Leggatta, QC, i P. Popata, barrister,

- w imieniu rzadu włoskiego, przez I. M. Braguglie, działajacego w charakterze petnomocnika, wspieranego przez P. Gentilię, avvocato dello Stato, [...]

[...] considérant les observations présentées:

- pour M. O'Byrne, par MM. S. Maskrey, QC, et H. Preston, barrister, mandatés par Mme K. Pickup, solicitor,

- pour Sanofi Pasteur MSD Ltd et Sanofi Pasteur SA, par MM. G. Leggatt, QC, et P. Popat, barrister,

- pour le gouvernement italien, par M. I. M. Braguglia, en qualité d'agent, assisté de M. P. Gentili, avvocato dello Stato, [...]

[...] ottaen huomioon huomautukset, jotka sille ovat esittäneet

- O'Byrne, edustajinaan S. Maskrey, QC, ja barrister H. Preston, solicitor K. Pickupin valtuuttamina,

- Sanofi Pasteur MSD Ltd ja Sanofi Pasteur SA, edustajinaan G. Leggatt, QC, ja barrister P. Popat,

- Italian hallitus, asiamiehenään I. M. Braguglia, avustajanaan avvocato dello Stato P. Gentili, [...]

Legal professions illustrate the possibly negative influence that cultural differences may have on translation. As in non-legal intercultural encounters, participants of discourse (and translators in this context) may produce messages that are only superficially mutually intelligible. Mutual comprehension may be affected by "invisible" at first sight differences in the conceptualization of the 
world, here: the legal reality. A similar problem arises in the context of other legal institutions, for instance translation of labels denoting different companies (e.g. "company with limited liability") can be challenging in that while rendering the name (type) of a company in the target language, the translator should take into consideration the competences associated with a particular formation rather than literal, semantic and dictionary meaning-related equivalents.

One of the most frequently discussed markers of legal language, i.e. the deontic "shall" is also problematic in translation. It is advertised in legal studies as a marker for deonticity, a modal to impose obligation, however, the Plain English campaign criticises it as an ambiguous verb used vaguely in legal contexts. For example, Robinson (1973: 39) says: "the use of 'shall' indicates that the legal subject is under obligation to act in accordance with the terms of the provision [...] it does not indicate something in relation to the future", but Lauchman (2005: 47), a plain language proponent, directs: "Shun the ambiguous shall. The word is used vaguely in five distinct ways, and it requires interpretation. [...] It is a "dead" word never heard in everyday conversation. [...] Shall has been interpreted in various ways by various judges; some say it means "must," but others insist it's just a recommendation, and means "should." Never suggest legal obligation. State it".

Thus, the deontic shall, as in: "This agreement shall be binding upon ..." or "Obligations of the Hirer shall not be assignable", must first be recognised as deontic and not merely epistemic. In English the verb "shall" receives situated interpretations, depending on the context of its use, but in legal texts the future readings seem to be merged with the deontic reading. Its interpretation is a function of the translator's expertise in English legal discourse and his or her ability to recognise conventions used by the people who drafted the document in question. In translation between Polish and English the problem of the future as opposed to the deontic meaning of the verb shall is also of special interest (cf. e.g. Witczak-Plisiecka 2007, 2009). Technically, English does not have verb forms that would be marked for the future tense use; instead it uses various phrases which specialised to convey reference to the future. Polish, on the other hand, has morphologically marked future tense, however, legal deonticity can be conveyed with the use of both the present and the future tense, just like both the Present Simple form and the construction with "shall" can be a vehicle for deonticity in English. For instance, deontic meaning can be carried by both, cf.: "The national flag shall be white and red" and "The national flag is white and red". In many contexts deonticity can also be conveyed with the use of other modal verbs, most often "must".

When a translation process is attempted, the varied shades of meaning of modal verbs, including the contentious "shall", must be recognised, and their pragmatic 
function rendered in the target language in a functional way, i.e. with the closest possible pragmatic and legal function-oriented force.

\subsection{Intersemiotic equivalence and legal translation}

With reference to the intersemiotic plane it is noteworthy that legal translation pertains to legal systems. It is performed in the interface of the realm of law and the imperfect world of ordinary people who use relatively imprecise language.

Lawyers often refer to the concept of "plain meaning". As a legal dictionary suggests (law.com.dictionary): "Unless defined in the statute, every word or phrase in a statute should be accorded its plain and ordinary meaning, considering the context in which the words are used." However, legal semantics cannot be directly identified with common language semantics (cf. Wojtczak and WitczakPlisiecka 2019). Legal language performs a special function, it is much different from other specialised languages, such as the language of medicine, or the language of engineering. Despite its homogenous appearance, it merges phrases which denote, establish, and re-establish legal reality with ordinary phrases which are used in non-special sense. This is why, although legal translation is not similar to audiodescription or translation between language and gestures, some aspects of it can be recognised as a search for intersemiotic equivalence as the translator, if he or she is to produce a reliable and faithful product, must see through the systemic significance of the language used, and represent the meaning of the source text (discourse) so that it could function in the closest possible way in the target language.

The comprehension of what words mean, and how they do it, can be much different within the legal community and among linguists. The very concept of "plain meaning" can be seen as if through different lenses.

In the case Smith v. United States (508 U.S. 223) ${ }^{3}$, the defendant, Smith, was caught trying to barter an automatic weapon with a silencer for two ounces of cocaine. He was caught in the act and charged with drug trafficking, but there was also a question of possible aggravated offence related to the circumstance of "using firearm", while committing the crime. Following the statutory formulae which set higher offences for cases in which a defendant "uses or carries a firearm [...] during and in relation" to another crime or violence of drug trafficking. Smith faced the possibility of serving additional 30 years for using a gun with a silencer, which circumstance could potentially cost a further five years. The question was: Did he use the gun? Smith tried to barter his gun for cocaine, but never produced it, did not threaten anyone with it, did not point it at anybody and had it in his bag all the time.

Eventually, at the level of the US Supreme Court, in 1993, it was decided in a six to three vote that Smith used the gun in the statutory sense with Judge O'Connor explaining that: "Had Congress intended the narrow construction

${ }^{3} \mathrm{cf.}$ https://supreme.justia.com/cases/federal/us/508/223/ 
petitioner urges, it could have so indicated. It did not, and we decline to introduce that additional requirement on our own."

The case seems to illustrate an important difference that can be seen between the understanding of "plain meaning" on the part of legal professionals and lay people. There are few lay people who would agree that Smith's performance could count as "using" the gun. On the other hand lawyers' approach to lexical meaning in this context is much more "technical" (it is noteworthy of course that the opinion was not unanimous, but still most of the lawyers agreed that it was a "use") in their legal semantics. As it was said in the case: "In affirming Smith's conviction and sentence, the Court [...] held that $\S$ 924(c)(I)'s plain language imposes no requirement that a firearm be "use[d]" as a weapon, but applies to any use of a gun that facilitates in any manner the commission of a drug offense." (https://supreme.justia.com/cases/federal/us/508/223/). Evidently, trying to apply, but not to make law, the Supreme Court also decided that the wording of the statute did not allow for any "narrowing" of the sense of the word "use", for instance to interpret it as "use to attack". This legal interpretation disagrees with intuitions of ordinary people with regard to "using the gun". In fact, even one of the Supreme Court judges, Antonin Scalia, a famous (or notorious) textualist, in his dissent opinion pointed out to the fact that, for instance, using a walking stick that had belonged to one's grandfather as decoration in the hall would not constitute an act of "using a walking stick" in a proper sense of the phrase. $\mathrm{He}$ also said: "even the criminal who pistol-whips his victim has not used a firearm within the meaning of $\S 924(\mathrm{c})(1)$, for firearms are intended to be fired or brandished, not used as bludgeons".

The example shows the significance of legal interpretation, but also the fact that legal language can itself be underdetermined. As Hart pointed out: "Natural languages like English are [...] irreducibly open-textured. [...] [W]e should not cherish, even as an ideal, the conception of a rule so detailed that the question whether it applied or not to a particular case was always settled in advance, and never involved, at the point of actual application, a fresh choice between open alternatives. Put shortly, the reason is that the necessity for such choice is thrust upon us because we are men, not gods."(Hart 1961: 127-8).

There are numerous contexts where lawyers seem to act with a tacit recognition of the fact that language is underdetermined, forcing categorization that is clearly pragmatic in nature. There have been judgements in which snails were classified as fish, carrot as fruit, and tomatoes as vegetable. It was not uncommon to refer to "plain meaning" in such contexts. For instance in Nix vs. Hedden, 149 U.S. 304 (1983), in an attempt to explain "ordinary and plain meaning", it was claimed that: "Botanically speaking, tomatoes are the fruit of a vine, just as are cucumbers, squashes, beans, and peas. But in the common language of the people, whether sellers or consumers of provisions, all these are vegetables which are grown in kitchen gardens, and which, whether eaten cooked or raw, are, like potatoes, carrots, parsnips, turnips, beets, cauliflower, cabbage, celery, and lettuce, usually 
served at dinner in, with, or after the soup, fish, or meats which constitute the principal part of the repast, and not, like fruits generally, as dessert." ${ }^{\prime 4}$ Thus, contrary to common expectations, the law can sometimes legitimize, and in fact (re)construct, reality that is far scientific reality. The motivation is often pragmatic, but it also shows that the political can prevail over the scientific. In the case above the ruling was related to tax law. In the case of snails which were classified in the European Union in 2010 as fish, the problem was that of subsidies for fishers, and in the case of carrot in 2002, the practical problem was to allow the Portuguese to label their traditional product as carrot jam. There have been many more pragmatic rulings of that kind with one dating back to the $18^{\text {th }}$ century. As early as 1818, in New York, in a case focused on tax duty (or the lack of it) whales were classified as fish and not mammals against a scientist's expert opinion. Despite the fact that an expert witness was ready to present evidence to the contrary, the court followed the reasoning phrased in Mr. Anthon's statement and decided that the statue was "not to be interpreted according to the refined and learned opinions of naturalists [...] but to receive an interpretation according to their common and popular usage". Significantly, pointing to the fact that there was ample evidence that whales were mammals, Mitchell commented: "nobody

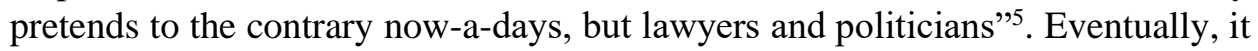
was clear that although scientifically whales are mammals, there are conflicting views on how to treat the oil of the whale, which for many business people was to be treated as a kind of "fish oil".

A lesson that such cases may offer for a translator is that engaging in legal translation he or she may mediate between two rather different cultures, either of which shows much complexity within. It is essential that the translator realise that both these cultures tend to treat language differently, including its semantics and social functions. This can be further illustrated with numerous superficially vague expressions found in legislation and legal discourse in general. Such phrases include, for instance: "with due care", "reasonable care", within "reasonable limits" are commonly seen as vague. Similarly, It Is difficult to define what "due regards" or "due diligence" mean. Phrases such as "cruel and unusual punishment", "satisfactory condition", "measures having equivalent effect", "relevant measures", "beyond reasonable doubt", "the reasonable use", "acute hardship", are left to be interpreted in particular contexts. In selected contexts it is the performers of the described actions that have to define them (e.g. drivers must not to perform "careless driving"), on other occasions, or in the case of a legal dispute, lawyers will establish the exact meaning. The phrases are examples of formulaic language and tend not to be seen as vague, but rather as ambiguous within the legal community as they function as markers for legal institutions, whether such institutions are less or more formally defined in the legal system (cf. Witczak-Plisiecka 2008). On the other hand, some degree of vagueness is

\footnotetext{
${ }^{4}$ http://caselaw.lp.findlaw.com/cgi-bin/getcase.pl?court=US\&vol=149\&invol=304

${ }^{5}$ http://www.lateralmag.com/articles/issue-29/when-whales-were-fish
} 
necessary in the legal discourse and cannot be seen as a drawback (cf. e.g. Endicott 2000). It is not a sign of imperfection, but a feature of legal discourse, which, in the case of legislative texts, needs to be applicable in future contexts whose details cannot be directly envisaged at the time of drafting. It is worth signalling that in the context of translation, the recognition of the type of vagueness present in the text will also be important.

Another aspect of legal communication and the understanding of pairing of form and function (meaning) in legal contexts involves the distribution of power manifested in the interface of law and lay community (cf. e.g. Fetzer and WitczakPlisiecka, in press), where structurally similar forms may selectively receive different interpretations depending on the type of relationship between the participants involved in the interaction. Similarly to other contexts where indirectness is involved, translators may be faced with additional difficulties.

Finally, it is important which function the translation is to serve, e.g. is it going to be the normative, the informative, or the judiciary, court-related function (cf. Cao 2007, pp.10ff.), is the original function of the text prescriptive, descriptive, or mixed (cf. Sarcevic 1997), etc. Significantly, in her tacit recognition of the difficulties involved in communication between lawyers and non-lawyers, as early as in 1997, Sarcevic defined the whole of legal translation as a "special-purpose communication" (Sarcevic 1997, p. 9), communication between specialists, excluding any encounters between lawyers and ordinary people. A perspective like this would naturally exclude much of theorising about intralingual and intersemiotic equivalence in the context of law and yet, such encounters are part of today's world.

Once again, it is evident that legal translation in numerous contexts, and In Its entirety, will involve intercultural encounters with likely differences in values, beliefs and intentions on both sides.

\section{Conclusions}

Intercultural insights and the recognition of differences between various legal cultures, and the terminological peculiarities inherent in them is needed both in comprehending the law and translating its language. Many of the difficulties that arise in legal translation are directly related to legal culture issues, the relatively invisible layer of beliefs, attitudes and values that "insiders" would take for granted.

Recognition of multiple intercultural differences is naturally done on different levels which, in the context of translation, can be related to Jakobson's types of equivalence. Firstly, a translator needs to see the difference between legal language and ordinary language within one natural language system and one legal system; the translator also needs to see the language-related differences in the context of "experts" and "lay people". On the interlingual level there are 
"ordinary" differences between natural languages, but legal contexts will enrich them so that they embrace both different languages and different legal systems. At this level, depending on the Skopos ideas, i.e. the main purpose that the translator has accepted, and the function that the target language text (discourse) is to serve, lexical equivalence may not fully reflect functional equivalence. In such cases the closest lexical equivalent may not be the best equivalent. Finally, at the intersemiotic plane, differences related to coding, non-transparent presuppositions (e.g. different standards, expectations) must be taken into consideration.

It seems that in order to be a good legal translator it is not enough to be a good linguist as there are crucial differences between how lawyers and lay people perceive legal language and its function in the system of law. Thus, starting with quite mundane differences between legal discourse (written or spoken), a specialised variety, vis-à-vis ordinary language, translators must proceed to embrace cultural issues and different perceptions inherent in both rather detached worlds, accepting that legal translation is an interdisciplinary activity.

\section{References}

Austin, John L. 1962/1975. How to Do Things with Words. The William James Lectures delivered at Harvard University in 1955, $2^{\text {nd }}$ ed., edited by J.O. Urmson and Marina Sbisa. Oxford: Clarendon Press.

Bakhtin, Mikhail. M. 1981. The Dialogic Imagination: Four Essays [ed. by M. Holquist; trans. C. Emerson and M. Holquist]. Austin: University of Texas Press.

Bakhtin, Mikhail M. 1986. Speech Genres and Other Late Essays [ed. by C. Emerson and M. Holquist; trans. V. W. McGee]. Austin: University of Texas Press.

Biber, Douglas, Stig Johansson, Geoffrey Leech, Susan Conrad \& Edward Finegan (1999) Longman Grammar of Spoken and Written English. Harlow: Longman.

Cao, Deborah. 2007. Translating Law. Clevedon: Multilingual Matters Ltd.

Charrow, Robert P. \& Veda R. Charrow. 1979. "Making Legal Language Understandable: A Psycholinguistic Study of Jury Instructions”. Columbia Law Review. Vol. 79, No. 7, pp. 13061374. https://doi.org/10.2307/1121842; https://www.jstor.org/stable/1121842

Crystal, David. 2018. The Cambridge Encyclopedia of the English Language. Cambridge:

Cambridge University Press. https://doi.org/10.1017/9781108528931

Danet, Brenda. 1980. "Language in the legal process". Law and Society Review 14, pp. 445-564. https://www.jstor.org/stable/i354491; https://doi.org/10.2307/3053192.

Endicott, Timothy A.O. 2000. Vagueness in Law. Oxford: Oxford University Press. https://doi.org/10.1093/acprof:oso/9780198268406.001.0001

Fetzer, Anita \& Iwona Witczak-Plisiecka. 2021 (in press). "Argumentative, Political and Legal Discourse”. In: The Cambridge Handbook of Sociopragmatics, ed. by M. Haugh, D. Kádár \& M. Terkourafi. Cambridge: Cambridge University Press, pp. 520-543.

Frank, Jerome N. 1947. "Words and music: Some remarks on statutory interpretation". Columbia Law Review. No. 8, pp. 1259-1278. https://doi.org/10.2307/1118098

Gibbons, John. 2003. Forensic Linguistics: An Introduction to Language in the Justice System. London: Blackwell.

Gotti, Maurizio. (2003) Specialized Discourse. Linguistic Features and Changing Conventions. Bern: Peter Lang.

Hart, Herbert L. A. 1961/1994. The Concept of Law (2nd ed.). Oxford/New York: Clarendon Press. 
Huddleston, Rodney, Geoffrey K. Pullum et al. (2002) The Cambridge Grammar of the English Language. Cambridge: CUP.

Hutton, Christopher. 1995. 'Law lessons for linguists? Accountability and acts of professional communication', Language and Communication 16(3): 205-14. https://doi.org/10.1016/0271-5309(96)00010-9

Hutton, Chris. 2009. Language, Meaning and the Law. Edinburgh: Edinburgh University Press.

Jakobson, Roman. 1959. "On Linguistic Aspects of Translation”. In: On Translation, ed. by R. A. Brower. Cambridge, Mass.: Harvard University Press, pp. 232-239.

Jopek-Bosiacka, Anna. 2019 Teoretyczno-prawne I logiczne uwarunkowania przekładu prawnego. Warszawa: Wolters Kluwer.

Lauchman, Richard. 2001-2005. Plain Language. A handbook for writers in the U.S. Government. Available at http://www.lauchmangroup.com/PDFfiles/ PLHandbook.PDF (accessed May 2007).

Mellinkoff, David. 1963. The Language of the Law. Boston: Little, Brown \& Co.

Quirk, Randolph, Sidney Greenboum, Geoffrey Leech \& Jan Svartvik (1992) A Comprehensive Grammar of the English Language. London \& New York: Longman.

Robinson, Stanley. 1973. Drafting: Its application to conveyancing and commercial documents. London: Butterworths.

Sarcevic, Susan. 1997. New Approach to Legal Translation. The Hague: Kluwer Law International.

Sugarman, David \& H.L.A. Hart. 2005. "Hart Interviewed: H.L.A. Hart in Conversation with David Sugarman" (interview 1988) Journal of Law and Society, Vol. 32, No. 2 (Jun., 2005), pp. 267-293 http://ezproxy.library.nyu.edu:2063/stable/3557228

Tiersma, Peter M. 1999. Legal Language. Chicago: The University of Chicago Press.

Witczak-Plisiecka, Iwona. 2001 (ms). Semantic and Pragmatic Aspects of Speech Acts in English Legal Texts. PhD dissertation, University of Lodz, Poland.

Witczak-Plisiecka, Iwona. 2005. "English legal texts in translation-the relevance-theoretic approach" Relevance Studies in Poland 2, pp. 169-181.

Witczak-Plisiecka, Iwona. 2007. "Linguistic Aspects of the deontic shall in the legal context" In: Language and the Law: International Outlooks, ed. by K. Kredens and S. Goźdź-Roszkowski.. Frankfurt: Peter Lang, pp. 181-199.

Witczak-Plisiecka, Iwona. 2008. "The Relevance of Vague Expressions in the Law" Research in Language 6, pp. 167-187.

Witczak-Plisiecka, Iwona. 2009. "Legal Speech Acts in a Cognitive Linguistic Perspective - Focus on Modality" Comparative Legilinguistics (International Journal for Legal Communication) 1: 1, pp. 159-175.

Witczak-Plisiecka, Iwona. 2013a. From Speech Acts to Speech Actions. Łódź: Lodz University Press.

Witczak-Plisiecka, Iwona. 2013b. "Speech action in legal contexts". In Marina Sbisà \& K. Turner (eds.), Pragmatics of Speech Actions [Handbook of pragmatics; Part 2], Berlin/Boston:

Mouton de Gruyter, pp. 613-658.

Witczak-Plisiecka, Iwona. 2016. "The interface of language and culture in the legal context-some teaching implications". In: Languages, Culture, Media, ed. by M. Kopytowska, B. Lewandowska-Tomaszczyk, J. Osborne, J. Schmied, K. Yumlu. Chambéry: Editions de l’Université de Savoie Mont Blanc, pp. 323-338, ISBN: 978-2-919732-75-3

Wojtczak, Sylwia \& Iwona Witczak-Plisiecka. 2019. "Metaphors and Legal Language: A few comments on ordinary, specialised, and legal meaning". Research in Language 17: 3, pp. 273295. DOI: https://doi.org/10.18778/1731-7533.17.3.04

Wojtczak, Sylwia, Iwona Witczak-Plisiecka, Rafał Augustyn. 2017. Metafory konceptualne jako narzędzia rozumowania i poznania prawniczego [Conceptual Metaphors as Tools in Legal Reasoning and Cognition]. Warszawa: Wolters Kluwer.

Wróblewski, Jerzy, 1948. Język prawny i prawniczy. Kraków: Polska Akademia Umiejętności.

Wróblewski, Jerzy. 1959. Zagadnienia teorii wyktadni prawa ludowego. Warszawa. 
Wróblewski, Jerzy. 1984. "Zagadnienia terminologii nauk prawnych” [Terminology issues in legal sciences]. Nauka Polska 3, pp. 80-82.

Internet sites:

http://caselaw.lp.findlaw.com/cgi-bin/getcase.pl?court=US\&vol=149\&invol=304 (accessed

February 2019)

CLARITY: http://www.clarity-international.net/journals/56.pdf (accessed May 2016)

https://www.legislation.gov.uk/ukpga/1999/22/notes/contents (Justice Act 1999; accessed February 2019)

https://www.worldwidewords.org/articles/probono.htm (accessed June 2010)

InfoCuria Case-Law; C-127/04 - O’Byrne; https://curia.europa.eu (accessed February 2019)

law.com.dictionary (accessed May 2016)

https://supreme.justia.com/cases/federal/us/508/223/ (on Smith vs. United States (508 U.S. 223)

accessed February 2019)

http://www.lateralmag.com/articles/issue-29/when-whales-were-fish (accessed February 2019)

\section{Bio-note}

Iwona Witczak-Plisiecka is associate professor at the University of Lodz, Poland, head of Department of English Language and Applied Linguistics. Her research interests include sociolinguistics, speech acts and actions and their theoretical accounts in the interface of semantics and linguistic pragmatics. She is also interested in communication in semantically-restricted domains, and legal translation in theory and practice. 